\title{
Studi Pendahuluan Sintesis Nano-partikel Cobalt-ferit Hasil Ko-presipitasi
}

\author{
Rafika Rahmawati, ${ }^{*}$ Suharyana, dan Budi Purnama \\ Jurusan Fisika, Fakultas Matematika dan Ilmu Pengetahuan Alam (FMIPA) Universitas Sebelas Maret, \\ Jl. Ir. Sutami 36A Kentingan, Surakarta 57126
}

Intisari

\begin{abstract}
Studi pendahuluan sintesis nano partikel ferromagnetik cobalt ferrit dengan metode ko-presipitasi dilanjutkan dengan aniling telah dilakukan. Aniling dilakukan pada keadaan atmosfir. Hasil karakterisasi TG-DTA memperlihatkan bahwa proses pertumbuhan kristal berada pada temperatur lebih dari $500^{\circ} \mathrm{C}$. Hasil analisis struktur kristal memperlihatkan sampel yang terbentuk adalah $\mathrm{CoFe}_{2} \mathrm{O}_{4}$ dengan puncak spektrum berada pada sudut $2 \theta$ $=35,7^{\circ}$ bersesuaian dengan bidang indeks Miller $(\mathrm{hkl})=311$ dengan ukuran butiran sekitar 28,5 $\mathrm{nm}$. Akhirnya, hasil analisis vibrating sampel magnetometer menegaskan bahwa sampel cobalt-ferit memiliki medan coersif $\mathrm{H}_{C}=313 \mathrm{Oe}$.
\end{abstract}

\begin{abstract}
Preliminary study on the synthesis of ferromagnetic cobalt ferrite nanoparticles by co-precipitation method followed by annealing process has been done. Annealing was performed at atmospheric condition. The TGDTA characterization results showed that the crystal growth process occured at above $500^{\circ} \mathrm{C}$. The XRD spectra of the sample showed that the crystal structure of $\mathrm{CoFe}_{2} \mathrm{O}_{4}$ was confirmed with the main diffraction peak at $2 \theta$ $=35.7^{\circ}$ corresponding to $(\mathrm{hkl})$ indeks of 311 . Finally, analysis of vibrating sample magnetometer indicated that cobalt ferrite sample had coercive field of $\mathrm{H}_{C}=313$ Oe.
\end{abstract}

KATA KUNCI: Cobalt Ferrite, co-precipitation, crystal, coersivity

\section{PENDAHULUAN}

Bahan magnetik merupakan kata kunci bagi beragam devais elektronika modern. Salah satu bahan magent yang menjadi fokus perhatian para peneliti adalah cobalt ferit $\left(\mathrm{CoFe}_{2} \mathrm{O}_{4}\right)$. Kestabilan kimia, kekuatan mekanik dan anisotropi magnetik yang tinggi adalah karakteristik unggul yang mampu membuka peluang beragam devais [1]. Aplikasi awal yang dapat ditemukan dari pemanfaatan bahan magnet ini hingga kini adalah medium perekaman seperti piringan hitam, tape recording, compact disc hingga piringan HDD Hard Disk [2]. Aplikasi di bidang medis pada saat ini adalah usaha penggunaan material magnet sebagai pembawa obat sehingga dapat secara efektif menjangkau target yang tidak dapat dijangkau oleh obat konvensional [3].

Beragam metode sintesis bahan magnetik berbasis oksida ini (cobalt ferit), antara lain metode kalsinasi [5], sonochemical atau secara kimia dengan menggunakan $\mathrm{Fe}(\mathrm{CO})_{5}[6]$, subtitusi logam bahan magnet lain [7], dan yang terkini adalah metode combustion, baik self combustion [8] maupun auto combustion [9]. Selain itu ada metode yang populer dalam kurun waktu satu dekade terakhir ini yang dikenal metode pengendapan (co-precipitation) [10].

Prosedur pengendapan dalam sintesis cobalt ferit ini san-

\footnotetext{
*E-MAIL: rafikarahmawati@gmail.com
}

gat menarik karena ukuran butiran dapat dikontrol melalui perubahan prosedur reaksi kimia secara sederhana. Sebagaimana telah diketahui bahwa karakteristik magnetik sangat dipengaruhi oleh ukuran butiran bahan magnet terlebih orde nanometer [11]. Sementara itu pada metode-metode lainnya ukuran butiran tidak dapat dikontrol dalam prosedur sintesisnya.

Adapun modifikasi dari metode inipun telah dilakukan antara lain dengan menganalisis pengaruh laju tetesan terhadap koersivitas [12], melakukan reverse ko-presipitasi (pembalik larutan pengendap) [13] dan juga telah diamati pengaruh doping material lain pada metode ini [14].

Namun daripada itu, perlu dilakukan studi pendahuluan sintesis menggunakan kobalt ferrit secara intensif dengan menggunakan laboratorium standar di Indonesia.

Dalam makalah ini, studi pendahuluan sintesis nanopartikel feromagnetik cobalt ferit dengan metode pengendapan akan dilaporkan. Karakterisasi bahan hasil sintesis meliputi TGDTA, XRD, dan VSM.

\section{METODE PENELITIAN}

$\mathrm{Fe}\left(\mathrm{NO}_{3}\right)_{3} \cdot 9 \mathrm{H}_{2} \mathrm{O}$ sebanyak $0,002 \mathrm{~mol}$ dan $\mathrm{Co}\left(\mathrm{NO}_{3}\right)_{2} \cdot 6 \mathrm{H}_{2} \mathrm{O}$ 0,01 mol dilarutkan dalam $200 \mathrm{ml}$ aquades selanjutnya disebut larutan logam magnet. Larutan precipitan menggunakan $\mathrm{NaOH}$ 4,8 M sebanyak $100 \mathrm{ml}$. Selanjutnya, larutan logam magnet diteteskan sedikit demi sedikit (dititrasi) ke dalam 


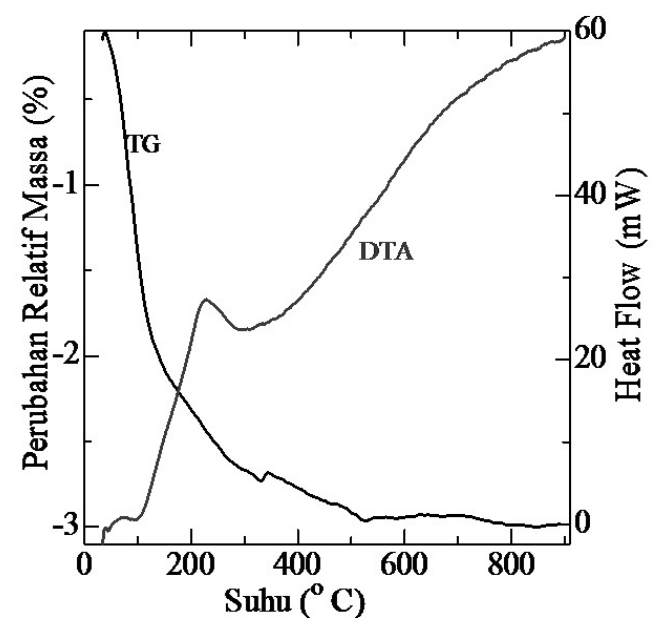

Gambar 1: Tipikal kurva TG-DTA sampel cobalt-ferit.

larutan $\mathrm{NaOH}$. Selama proses berlangsung, larutan diaduk dengan magnetik stirer kecepatan putar $1500 \mathrm{rpm}$ dan temperatur larutan dipertahankan sebesar $95^{\circ} \mathrm{C}$. Setelah terbentuk precursor berwarna coklat gelap, sampel dicuci dengan menggunakan aquades dan aceton hingga benar-benar bersih. Selanjutnya sampel dikeringkan dalam tungku pemanas (oven) pada temperatur $100^{\circ} \mathrm{C}$. Sampel yang telah kering digerus selama 2 jam untuk mendapatkan ukuran yang homogen. Selanjutnya sampel di-aniling pada temperatur $600^{\circ} \mathrm{C}$ dengan variasi waktu annealing yaitu 2 jam, 6 jam dan 11 jam.

Sampel yang telah terbentuk dianalisa dengan menggunakan TG-DTA, XRD dan VSM.

\section{HASIL DAN PEMBAHASAN}

Gambar 1 menunjukan tipikal kurva TG-DTA sampel cobalt ferit hasil sintesis, kurva TG teramati secara jelas bahwa perubahan relatif massa selama proses pemanasan berkurang kurang lebih $3 \%$. Penurunan masa relatif pertama terjadi pada rentang pemanasan dari temperatur ruang s.d. $\mathrm{T}$ $=320^{\circ} \mathrm{C}$ dengan penurunan masa relatif kurang lebih $2,7 \%$. Penurunan ini dapat dikaitkan dengan sisa-sisa hidrokarbon pada proses sintesis. Penurunan masa relatih kedua terjadi pada rentang temperatur $\mathrm{T}=320-530^{\circ} \mathrm{C}$. Masa relatif menurun sebesar $2,9 \%$ dari massa mula-mula. Jika dibandingkan dari fase penurunan massa sebelumnya, tahapan ini hanya memberikan kehilangan masa sebesar 0,2\% (2,9-2,7). Hasil ini dapat diasosiasikan dengan proses dislokasi nanopartikel menuju konfigurasi stabil. Tahapan penurunan masa terakhir berlangsung pada temperatur $\mathrm{T}=530-900^{\circ} \mathrm{C}$. Sampel dapat dinyatakan tidak mengalami kehilangan massa lagi. Durasi waktu pemanasan dapat diprediksi digunakan untuk penumbuhan kristal sampel cobalt-ferit.

Sedangkan dari karakterisasi DTA diperoleh kenyataan bahwa pada temperatur $230^{\circ} \mathrm{C}$ teramati puncak karaketristik yang bersesuaian dengan heat flow sebesar 27,3 mW. Di atas temperatur tersebut, kurva DTA meningkat secara drastik

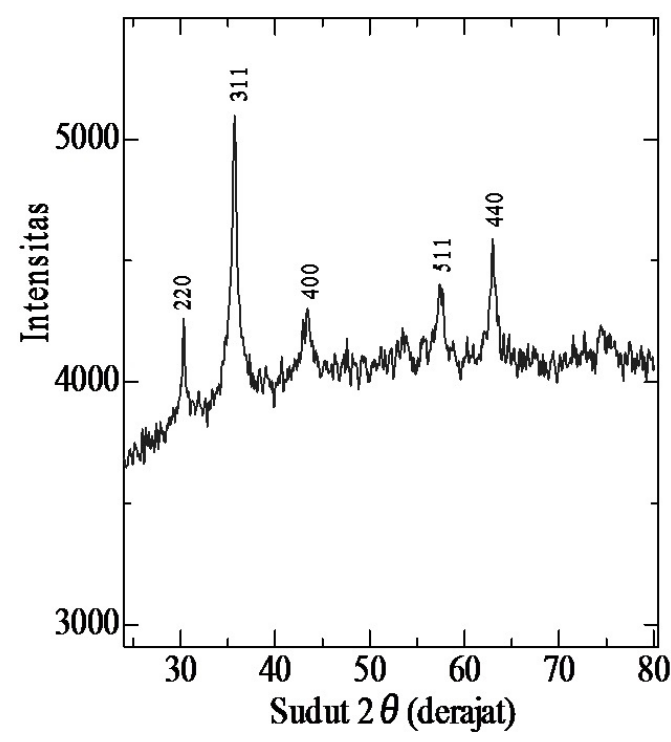

Gambar 2: Tipikal spektrum XRD cobalt-ferit $\left(\mathrm{CoFe}_{2} \mathrm{O}_{4}\right)$ hasil aniling pada temperatur $\mathrm{T}=600^{\circ} \mathrm{C}$ selama 2 jam.

dengan kenaikan temperatur. Hasil ini memberi informasi bahwa proses aniling guna penumbuhan struktur kristal nano partikel cobalt-ferit harus dilakukan di atas temperatur $500^{\circ} \mathrm{C}$.

Gambar 2 menunjukan spektrograf x-ray diffraction (XRD) sampel serbuk nano partikel cobalt-ferit hasil aniling precursor pada temperatur $600^{\circ} \mathrm{C}$ selama 2 jam pada keadaan atmosfir. Hasil XRD menunjukkan kesesuaian dengan data referensi ICDD nomor 221086 yang menegaskan bahwa sampel yang terbentuk adalah $\mathrm{CoFe}_{2} \mathrm{O}_{4}$. Puncak spektrum XRD terjadi pada sudut $2 \theta=35,73^{\circ}$. Dari gambar dapat diketahui pula bahwa pengotor dari unsur atau oksida lainnya tidak hadir selama proses aniling. Hal ini juga menandaskan bahwa proses sintesis berlangsung tanpa memberikan sisa hidrokarbon yang seringkali hadir sebagai pengotor.

Perhitungan diameter butiran kristalit berdasar rumus Scherer pada puncak maksimum memberikan nilai seorde dengan hasil yang telah dipublikasikan Maaz [3] sebelumnya sebesar $28,5 \mathrm{~nm}$.

Kurva histeresis nano partikel cobalt-ferit ditunjukan pada Gambar 3. Sapuan medan eksternal dari -2000 Oe sampai dengan +2000 Oe cukup membuat sampel termagnetisasi secara lengkap yang terungkap dari kurva histeresis yang terbentuk dengan magnetisasi jenuh $\mathrm{MS}=185 \mathrm{emu} / \mathrm{cc}$. Tahapan magnetisasi melalui domain wall nuklasi dilanjutkan dengan perambatan domain disinyalir terjadi selama proses magnetisasi. Berdasarkan satu siklus histeresis tersebut diperoleh bahwa medan koersif sebesar $\mathrm{H}_{C}=313$ Oe digunakan untuk mengkompensasi atau meniadakan magnetisasi sisa/remanen $\mathrm{Mr}=58,4 \mathrm{emu} / \mathrm{cc}$. 


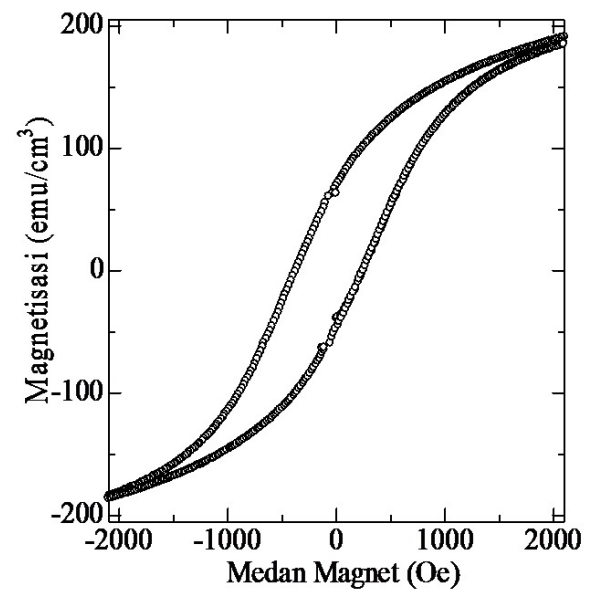

Gambar 3: Kurva histeresis nanopartikel cobalt-ferit.

\section{SIMPULAN}

Studi pendahuluan sintesis dan karakterisasi nano partikel ferromagnetik cobalt ferrit dengan metode ko-presipitasi telah dilakukan. Proses aniling dilakukan pada keadaan atmosfir. Karakterisasi fisis meliputi TG-DTA, XRD dan VSM. Hasil karakterisasi TG-DTA memperlihatkan bahwa proses pertumbuhan kristal berada pada temperatur lebih dari $500^{\circ} \mathrm{C}$. Hasil analisis struktur kristal memperlihatkan sampel yang terbentuk adalah $\mathrm{CoFe}_{2} \mathrm{O}_{4}$ dengan puncak spektrum berada pada sudut $2 \theta=35,7^{\circ}$ bersesuaian dengan bidang indeks Miller $(\mathrm{hkl})=311$ dengan ukuran butiran sekitar 28,5 nm. Akhirnya, hasil analisis vibrating sampel magnetometer menegaskan bahwa sampel cobalt-ferit memiliki medan coersif $\mathrm{H}_{C}=313$ Oe.
[1] K.O. Zhang, et al., Journal of Applied Physics, 111(3), 07B525 (2012).

[2] J.Z. Msomi, et al., Journal of Magnetism and Magnetic Materials, 373, 68-73 (2015).

[3] K.S. Maaz, et al., Journal of Magnetism and Magnetic Materials, 321, 1838-1842 (2009).

[4] P. Sardjono, dkk., Aplikasi Magnet Permanen di Indonesia: Data Pasar dan Pengembangan Material Magnet, Seminar Nasional Ilmu Pengetahuan Teknik, 28-29 Nov 2012.

[5] H. Hasan, et al., Iranian Journal of Material Science and Engineering, 2(2), 9-15 (2005).

[6] M. Sivakumar. et al., Journal of Magnetism and Magnetic Materials, 268, 95-104 (2004).

[7] A. Singh, et al., Journal of Ceramic Processing Research, 11(2), 241-249 (2010).

[8] C.E. Doroftei, et al., Journal of Optoelectronics And Advanced
Materials, 8(3), 1023-1027 (2012).

[9] H. Luo,et al., Journal of Magnetism an Magnetic Materials, 324, 2602-2608 (2012).

[10] K.S. Maaz, et al., Journal of Physica B, 404, 3947-3951 (2009).

[11] M. Pauzan Muh, et al., Pengaruh Ukuran Butir dan Struktur Kristal terhadap Sifat Kemagnetan pada Nanopartikel Magnetit $\left(\mathrm{Fe}_{3} \mathrm{O}_{4}\right)$, Prosiding Pertemuan Ilmiah XXVII HFI Jateng \& DIY, Solo, 23 Maret 2013 (ISSN: 0853-0823).

[12] M.Y. Cedeo, et al., Journal of Applied Physics, 103, $07 E 512$ (2008).

[13] N. Mahmed, et al., Jounal of Magnetism and Magnetic Materials, 353, 17 (2014).

[14] T. Shanmugavel, et al., Journal of Applied Physics, 1591, 496498 (2014). 